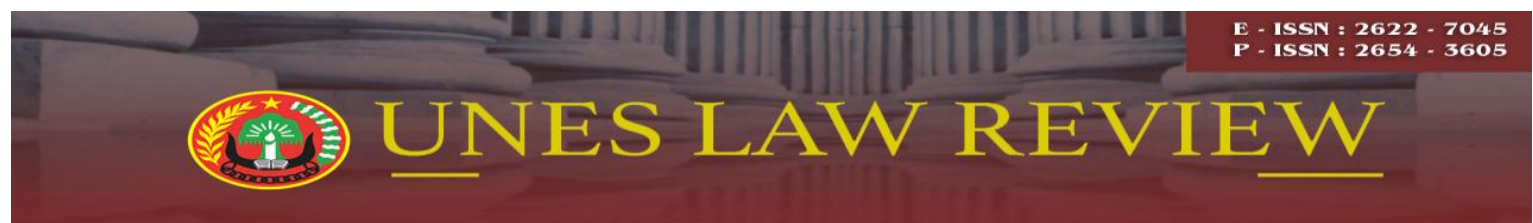

Email: uneslawreview@gmail.com

Online: http://review-unes.com/index.php/law

Volume 2, Issue 4, Juni 2020

\title{
PENYIDIKAN TERHADAP KEPALA DESA YANG DENGAN SENGAJA MELAKUKAN TINDAKAN YANG MENGUNTUNGKAN SALAH SATU PASANGAN CALON PADA SENTRA PENEGAKAN HUKUM TERPADU (Studi Pada Satuan Reserse Kriminal Kepolisian Resor Pariaman)
}

\author{
Alva Zakya Akbar \\ Program Magister Ilmu Hukum, Universitas Ekasakti, Padang, Indonesia \\ Email: alvazakya@gmail.com
}

\begin{abstract}
Village Heads deliberately take actions that benefit one of the candidates for regional head canditates are criminal acts regulated in Article 71 paragraph (1) and Article 188 of Law Number 10 Year 2016 concerning the Election of Governors, Regents and Mayors. In the election of Mayor Pariaman in 2018 there was a criminal offense due to the election of the state officials, namely the Village Head who during the face-to-face campaign between the community and the candidate pair gave remarks containing the invitation to choose the candidate pair. As a result of these actions, the Village Head was reported to the Gakkumdu Center for the Pariaman City Election Supervisory Committe and subsequently forwarded to the Pariaman Police Secretariat with Number: LP / B / 57 / III / 2018 / SPKT / Polres on March 29, 2018 for an investigation.
\end{abstract}

Kata Kunci: Penyidikan, Kepala Desa, Tindak Pidana Pemilihan

\section{PENDAHULUAN}

Salah satu bentuk Pemilu di Indonesia adalah Pemilihan Kepala Daerah. Di Indonesia, Pilkada langsung dilaksanakan sejak tahun 2005. Namun, dalam pelaksanaannya tidak menutup kemungkinan terjadi pelanggaran baik yang bersifat administratif maupun yang berupa tindak pidana. Tindak pidana pemilu di Indonesia dalam perkembangannya mengalami banyak perubahan baik berupa peningkatan jenis tindak pidana sampai perbedaan tentang penambahan sanksi pidana.

Tindak pidana yang terjadi pada pemlihan kepala daerah disebut tindak pidana pemilihan. Dalam Undang-undang Nomor 1 Tahun 2015 tentang Penetapan Peraturan Pemerintah Pengganti Undang-Undang Nomor 1 Tahun 2014 tentang Pemilihan Gubernur, Bupati, dan Walikota Menjadi Undang-Undang ditegaskan bahwa: ada empat institusi yang terlibat dalam penanganan perkara pidana pemilu, yaitu Panitia Pengawas Pemilu (Panwaslu), Kepolisian, Kejaksaan, dan Pengadilan. Untuk mengefektifkan penanganan 
perkara pelanggaran atau kejahatan terhadap pemilihan yang menyangkut pidana maka Panwaslu, Kepolisian, dan Kejaksaan membentuk Sentra Penegakan Hukum Terpadu (Sentra Gakkumdu). Dasar hukum pembentukan sentra gakkumdu adalah Pasal 152 ayat (1) Undang-undang Nomor 1 Tahun 2015 yang mengatur bahwa: "untuk menyamakan pemahaman dan pola penanganan tindak pidana Pemilihan, Bawaslu Provinsi, dan/atau Panwas Kabupaten/Kota, Kepolisian Daerah dan/atau Kepolisian Resor, dan Kejaksaan Tinggi dan/atau Kejaksaan Negeri membentuk sentra penegakan hukum terpadu.

Ketentuan lebih lanjut mengenai Sentra Gakkumdu diatur berdasarkan kesepakatan bersama antara Kepala Kepolisian Negara Republik Indonesia, Jaksa Agung Republik Indonesia, dan Ketua Badan Pengawas Pemilu Republik Indonesia Nomor: 15/NKB/BAWASLU/X/2015, Nomor: B/38/X/2015, Nomor: KEP-153/A/JA/10/2015 tentang Sentra Penegakan Hukum Terpadu. Keanggotaan Sentra Gakkumdu di tingkat kabupaten/kota anggotanya adalah Kepala Satuan Reserse Kriminal Polres/Polresta, Kepala Seksi Pidana Umum Kejaksaan Negeri dan Koordinator bidang Hukum dan Penanganan Pemilu Panwaslu Kabupaten/Kota.

Melalui Sentra Penegakan Hukum Terpadu ini diharapkan penyelesaian terhadap dugaan setiap tindak pidana Pemilu yang terjadi akan dapat berjalan secara optimal, mengingat bahwa untuk penyelesaian perkara tindak pidana Pemilu waktunya dibatasi mulai dari tahap penerimaan laporan, penyidikan, penuntutan dan pemeriksaan di sidang pengadilan, sehingga diperlukan tindakan yang cermat, cepat dan koordinatif antar anggota yang tergabung dalam Sentra Gakkumdu. Dengan demikian perbedaan persepsi dan pemahaman serta hambatan lain yang mungkin akan muncul dalam proses penegakan hukum tindak pidana Pemilu akan dapat teratasi.

Salah satu larangan dalam pemilihan kepala daerah adalah menyangkut tindakan pejabat daerah sebagaimana diatur dalam Pasal 71 ayat (1) Undang-undang Nomor 10 Tahun 2016 tentang Perubahan Kedua Atas Undang-Undang Nomor 1 Tahun 2015 tentang Pemilihan Gubernur, Bupati, dan Walikota Menjadi Undang-Undang, yang menyebutkan bahwa:

"Pejabat negara, pejabat daerah, pejabat aparatur sipil negara, anggota Tentara Nasional Indonesia (TNI)/Kepolisian Negara Republik Indonesia (Polri), dan Kepala Desa atau sebutan lain/Lurah, dilarang membuat putusan dan/atau tindakan yang menguntungkan atau merugikan salah satu pasangan calon”. 
Terhadap pelanggaran atas ketentuan di atas, merupakan tindak pidana pemilihan sebagaimana diatur dalam Pasal 188 Undang-undang Nomor 10 Tahun 2016 tentang Perubahan Kedua Atas Undang-Undang Nomor 1 Tahun 2015 tentang Pemilihan Gubernur, Bupati, dan Walikota Menjadi Undang-Undang,yang menyebutkan bahwa:

"Setiap pejabat negara, pejabat Aparatur Sipil Negara, dan Kepala Desa atau sebutan lain/Lurah yang dengan sengaja melanggar ketentuan sebagaimana dimaksud dalam Pasal 71, dipidana dengan pidana penjara paling singkat 1 (satu) bulan atau paling lama 6 (enam) bulan dan/atau denda paling sedikit Rp600.000,00 (enam ratus ribu rupiah) atau paling banyak Rp6.000.000,00 (enam juta rupiah)".

Pada pemilihan Walikota dan Wakil Walikota Pariaman Tahun 2018 juga terjadi tindak pidana pemilihan yang dilakukan oleh Imardi Darwin Pgl. Im, yang menjabat sebagai Kepala Desa Cimparuh sewaktu dilaksanakannya kampanye tatap muka antara masyarakat Dusun Lapai Desa Cimparuh Kecamatan Pariaman Tengah Kota Pariaman dengan Dr. H. Genius Umar, S.Sos, M.Si, Calon Walikota Nomor Urut 3, pada hari Minggu tanggal 18 Maret 2018 sekira pukul 14.00 WIB. Tersangka sebagai Kepala Desa memberikan kata sambutan yang berisi ajakan atau dorongan kepada masyarakat yang hadir dalam kampanye tersebut untuk bersama-sama mengantar Pasangan Calon Nomor Urut 3, Dr.H. Genius Umar, S.Sos, M.Si dan Drs. Mardison Mahyuddin, MM, menjadi Walikota dan Wakil Walikota Pariaman Periode 2018-20123. Atas kejadian tersebut Nadia Meria Jane yang bertindak selaku Anggota Panitia Pengawas Pemilihan Kecamatan Pariaman Tengah melaporkan ke Sentra Penegakan Hukum Terpadu (Gakkumdu) Panwaslih Kota Pariaman dan selanjutnya laporan tersebut diteruskan kepada Satuan Reserse Kriminal (Satreskrim) Kepolisian Resor Pariaman dengan Laporan Polisi Nomor: LP/57/B/III/2018/SPKT/Polres tanggal 29 Maret 2018. Terhadap perbuatan tersebut telah dilakukan penyidikan dan dikualifikasikan sebagai tindak pidana pemilihan sebagaimana diatur dalam Pasal 188 Undang-undang Nomor 1 Tahun 2015 juncto Pasal 71 Undangundang Nomor 10 Tahun 2016.

Berdasarkan latar belakang pemikiran di atas, maka permasalahan yang dibahas dalam tulisan ilmiah ini adalah sebagai berikut:

1. Bagaimanakah pelaksanaan penyidikan terhadap kepala desa yang dengan sengaja melakukan tindakan yang menguntungkan salah satu pasangan calon selama masa kampanye pada Satuan Reserse Kriminal Kepolisian Resor Pariaman? 
2. Apa sajakah kendala-kendala yang dihadapi dalam penyidikan terhadap kepala desa yang dengan sengaja melakukan tindakan yang menguntungkan salah satu pasangan calon selama masa kampanye pada Satuan Reserse Kriminal Kepolisian Resor Pariaman dan bagaimanakah upaya untuk mengatasinya?

\section{METODE PENELITIAN}

Penelitian ini adalah suatu penelitian yang bersifat deskriptif analitis, yaitu penelitian yang menggambarkan tentang pelaksanaan dan kendala-kendala dalam penyidikan terhadap kepala desa yang dengan sengaja melakukan tindakan yang menguntungkan salah satu pasangan calon pada sentra penegakan hukum di Satuan Reserse Kriminal Kepolisian Resor Pariaman. Metode pendekatan yang digunakan dalam penelitian ini adalah yuridis normative, yang didukung pendekatan yuridis empiris. Pendekatan yuridis normatif. yaitu pendekatan yang dilakukan dengan cara mempelajari ketentuan-ketentuan dan peraturan perundang-undangan (Ronny Hanitijo Soemitro, 1990:23). Pendekatan yuridis empiris dilakukan dengan cara mengumpulkan semua bahan dan data yang diperoleh dari lapangan yang berhubungan dengan permasalahan yang diteliti.

\section{HASIL PENELITIAN DAN PEMBAHASAN}

Pelaksanaan Penyidikan Terhadap Kepala Desa yang Dengan Sengaja Melakukan Tindakan yang Menguntungkan Salah Satu Pasangan Calon Selama Masa Kampanye Pada Satuan Reserse Kriminal Kepolisian Resor Pariaman

Penyidikan tindak pidana pemilihan kepala daerah, baru dapat dilakukan bilamana penyidik telah menerima laporan yang datang dari Sentra Penegakan Hukum Terpadu (Gakkumdu) Panitia Pengawas Pemilihan Kabupaten/Kota. Laporan tersebut harus tertulis yang ditandatangani oleh pelapor dan anggota Panwaslih yang membidangi penanganan pelanggaran dan tindak pidana pemilihan.

Berdasarkan hasil penelitian yang penulis lakukan diperoleh penjelasan bahwa Pelaksanaan penyidikan terhadap kepala desa yang dengan sengaja melakukan tindakan yang menguntungkan salah satu pasangan calon selama masa kampanye pada Satuan Reserse Kriminal Kepolisian Resor Pariaman dilakukan dengan mekanisme sebagai berikut: 
1. Menerima Laporan

Pada hari Kamis tanggal 29 Maret 2018, Kepolisian Resor Pariaman menerima laporan dari Nadia Meria Jane, anggota Panitia Pengawas Pemilihan Kecamatan (Panwascam) Pariaman Tengah melaporkan dugaan terjadinya tindak pidana pemilihan dan diregister dalam. Laporan Polisi Nomor: LP/B/57/III/2018/SPKT/Polres, tanggal 29 Maret 2018. Tindak pidana pemilihan yang dilaporkan yaitu Kepala Desa yang melakukan tindakan yang menguntungkan salah satu pasangan calon, yang diduga dilakukan oleh oknum Kepala Desa A.n. Imardi Darwin pada Kegiatan Kampanye Pasangan Calon Walikota dan Wakil Walikota Pariaman "DR.H Genius Umar, S,Sos, M.Si dan Drs. Mardison Mahyuddin, MM yang terjadi pada Hari Minggu tanggal 18 Maret 2018 sekira pukul 14.00 Wib bertempat di Dusun Lapai Desa Cimparuh Kec. Pariaman Tengah Kota Pariaman, sebagaimana dimaksud dalam Pasal 188 juncto pasal 71 Undang-Undang Nomor 10 Tahun 2016 tentang Perubahan Kedua Atas UndangUndang Nomor 1 Tahun 2015 Tentang Penetapan Peraturan Pemerintah Pengganti Undang-Undang Nomor 1 Tahun 2014 Tentang Pemilihan Gubernur, Bupati, Dan Walikota Menjadi Undang-Undang.

2. Melakukan Penyelidikan

Setelah menerima laporan tersebut pihak Satreskrim Polres Pariaman melakukan proses penyelidikan terhadap laporan tindak pidana Pemilihan, yang diduga dilakukan oleh oknum Kepala Desa A.n. Imardi Darwin pada Kegiatan Kampanye Pasangan Calon Walikota dan Wakil Walikota Pariaman "DR.H Genius Umar, S,Sos, M.Si dan Drs. Mardison Mahyuddin, MM. Selanjutnya berdasarkan hasil penyelidikan diperoleh kesimpulan bahwa laporan tersebut adalah tindak pidana pemilihan sehingga dapat dilanjutkan ke tahap penyidikan karena terdapat bukti permulaan yang cukup.

3. Melakukan Penyidikan

Penyidikan dimulai dengan dikeluarkan Surat Perintah Penyidikan Nomor: SP.Sidik/19/III/2018/Reskrim, tanggal 29 Maret 2018, Hal tersebut menandai secara formal prosedural bahwa penyidikan telah dimulai. Adapun langkah-langkah yang dilakukan adalah sebagai berikut:

a. Tindakan Pertama di Tempat Kejadian Perkara (TKP)

1) Mendatangi Tempat kejadian Perkara

Pada perkara tindak pidana Pemilihan yang dilakukan Kepala Desa, penyidik telah berhasil mengumpulkan barang bukti berupa:

a) 1 (Satu) (satu) Unit HP merek Xiaomi Redmi 4A warna Gold Nomor IMEI1 86540803209844, IMEI2 865408032029851;

b) 1 (lembar) poto Sdr Imardi Darwin memberikan Kata Sambutan pada acara kampanye di Dusun Lapai Desa Cimparuh Kec. Pariaman Tengah Kota Pariaman.

2) Mencatat saksi-saksi dan memintai keterangan nya.

Penyidik telah berhasil mengumpulkan saksi-saksi, yaitu: Saksi Fakta berjumlah 7 (tujuh) orang yaitu: Nadia Meria Jane S.Pd Pgl. Nadia; Mella Syafri Yanni.P,Se Pgl. Mella, Yudi Hartono Pgl Yudi, Ahmad Ginting Pgl Adiak, Priyaldi Pgl Yaldi, Irsad Pgl Irsad. 


\section{b. Pengolahan Tempat Kejadian Perkara (TKP)}

Penyidik Satreskrim Polres Pariaman, setelah mendatangi TKP, maka langkah selanjutnya adalah melakukan olah TKP dengan cara membuat berita acara dugaan terjadinya tindak pidana pemilihan dan membuat Sket gambar tempat kejadian perkara.

4. Melakukan Penggunaan Upaya Paksa

Pada pelaksanaan penyidikan, penyidik Satreskrim Polres Pariaman menggunakan kewenangannya untuk melakukan upaya paksa, yaitu:

a. Pemanggilan

Untuk melengkapi dan mempermudah jalannya penyidikan, maka penyidik melakukan pemanggilan terhadap pihak-pihak yang berhubungan dengan peristiwa yang dilaporkan, antara lain:

1) Terhadap Saksi Pelapor yang bernama Sdri Nadia Meria Jane, tidak dilakukan Pemanggilan dengan surat panggilan.

2) Terhadap Saksi yang bernama Sdri Mela Syafrianni, dilakukan Pemanggilan dengan surat panggilan Nomor : S.Pgl/54/III/2018/Reskrim, tanggal 30 Maret 2018.

3) Terhadap Saksi yang bernama Sdr Yudi Hartono, dilakukan Pemanggilan dengan surat panggilan Nomor : S.Pgl/55/III/2018/Reskrim, tanggal 30 Maret 2018.

4) Terhadap Saksi yang bernama Sdr Irsad, dilakukan Pemanggilan dengan surat panggilan Nomor: S.Pgl/56/III/2018/Reskrim, tanggal 30 Maret 2018.

5) Terhadap Saksi yang bernama Sdr Ahmad Ginting, dilakukan Pemanggilan dengan surat panggilan Nomor : S.Pgl/57/III/2018/Reskrim, tanggal 30 Maret 2018.

6) Terhadap Saksi yang bernama Sdr Rizalni, dilakukan Pemanggilan dengan surat panggilan Nomor : S.Pgl/58/III/2018/Reskrim, tanggal 30 Maret 2018.

7) Terhadap Saksi yang bernama Sdr Priyaldi, dilakukan Pemanggilan dengan surat panggilan Nomor : S.Pg1/59/III/2018/Reskrim, tanggal 30 Maret 2018.

b. Penangkapan

Dalam perkara ini, terhadap Tersangka Imardi Darwin tidak dilakukan penangkapan, Tersangka dipanggil dengan Surat Panggilan Nomor: S.Pg1/I/IV/2018, tanggal 02 April 2018. Tersangka Sudah diperiksa dan dimintai keterangan serta telah dibuatkan Berita Acara Pemeriksaan Tersangka pada Hari Kamis Tanggal 05 April 2018.

c. Penahanan

Dalam perkara ini terhadap tersangka Imardi Darwin tidak dilakukan penahanan berdasarkan pertimbangan penyidik secara subyektif dan obyektif serta tersangka sangat akomodatif dalam menjalani proses penyidikan.

d. Penyitaan

Penyitaan dalam perkara ini dilakukan terhadap barang bukti dengan Surat Perintah Penyitaan Nomor: SP.Sita/13/IV/2018/Reskrim, tanggal 03 April 2018, yang sudah dibuatkan berita acara penyitaannya. Adapun barang bukti yang disita adalah:

1) 1 (Satu) (satu) Unit HP merek Xiaomi Redmi 4A warna Gold Nomor IMEI1 86540803209844, IMEI2 865408032029851; 
2) 1 (lembar) poto Sdr Imardi Darwin memberikan Kata Sambutan pada acara kampanye di Dusun Lapai Desa Cimparuh Kec. Pariaman Tengah Kota Pariaman.

5. Pemeriksaan Saksi-saksi

1) Keterangan Saksi-saksi

Adapun saksi-saksi yang diperiksa dan dimintakan sebagai keterangan saksi dalam perkara tindak pidana Pemilihan adalah: Nadia Meria Jane S.Pd Pgl. Nadia; Mella Syafri Yanni.P,Se Pgl. Mella, Yudi Hartono Pgl Yudi, Ahmad Ginting Pgl Adiak, Priyaldi Pgl Yaldi, Irsad Pgl Irsad.

2) Keterangan Ahli Hukum Tata Negara

Keterangan Ahli, Dr. Khairul Fahmi, SH, M.H., Dosen Hukum Tata Negara Fakultas Hukum Universitas Andalas pada intinya menerangkan bahwa: "Kepala Desa yang masih aktif dilarang untuk melaksanakan atau ikut dalam kegiatan kampanye serta dilarang melakukan tindakan atau keputusan yang menguntungkan salah satu pasangan calon dalam Pilkada. Keuntungan yang diperoleh pasangan calon bukan hanya diukur dari beberapa suara yang nanti akan diperoleh pasangan tersebut, melainkan juga dapat diukur dengan bertambahnya peluang perolehan suara dari ajakan yang diberikan. Ketika ajakan memilih dilakukan oleh kepala desa, sebagai pejabat desa yang berpengaruh, ajakannya tentu akan memberikan keuntungan bagi calon yang diserukannya untuk memilih".

3) Keterangan Ahli Pidana

Keterangan Ahli, Yoserwan, S.H., M.H., L.L.M, Dosen Hukum Pidana Fakultas Hukum Universitas Andalas pada intinya menerangkan bahwa: "Pasal 71 juncto Pasal 188 Undang-undang Nomot 10 Tahun 2016 adalah termasuk dalam delik formil, karena dalam Pasal 71 yang dilarang adalah melakukan suatu perbuatan dalam hal ini membuat suatu keputusan atau tindakan, kalau suatu tindakan sudah terjadi atau terlaksana maka sudah menjadi tindak pidana. Dengan demikian untuk menentukan atau menilai sesuatu yang menguntungkan atau merugikan tidak harus dihubungkan dengan kerugian riil atau keuntungan riil yang berkaitan dengan kegiatan pemilihan, cukup bilamana sifat dari keputusan atau tindakan tersebut merugikan salah satu pasangan calon".

6. Pemeriksaan Tersangka

Tersangka yang diperiksa dalam perkara tindak pidana pemilihan adalah Imardi Darwin Pgl Im, yang mengakui bahwa: "benar pada hari Minggu tanggal 18 Maret 2018 bertempat di Dusun Lapai Desa Cimparuh Kec. Pariaman Tengah Kota Pariaman diadakan kegiatan kampanye pasangan calon walikota pariaman nomor urut 3. Di dalam acara tersebut Kepala Desa datang dan memberikan kata sambutan atau sepatah kata dari tokoh masyarakat, yang berisi ajakan dan dorongan untuk memilih paslon nomor urut 3 supaya menang dalam pemilihan walikota / wakil walikota pariaman tahun 2018 dan Tidak ada diajak oleh siapapun untuk memberikan kata sambutan dalam acara kampanye tersebut, Tersangka spontan tampil memberikan kata sambutan saat dipanggil tokoh masyarakat".

7. Selesainya Penyidikan

Pada kasus tindak pidana pemilihan, pihak penyidik telah menyerahkan tersangka dan barang bukti berupa kepada Penuntut Umum Kejaksaan Negeri Pariaman 
dan perkaranya sudah dinyatakan lengkap (P.21) sehingga dapat dlanjutkan ke proses penuntutan dan pemeriksaan sidang pengadilan.

Kendala-kendala yang Dihadapi Dalam Penyidikan Terhadap Kepala Desa yang Dengan Sengaja Melakukan Tindakan yang Menguntungkan Salah Satu Pasangan Calon Selama Masa Kampanye Pada Satuan Reserse Kriminal Kepolisian Resor Pariaman dan Upaya Untuk Mengatasinya

Penyidikan terhadap tindak pidana pemilihan berupa kepala desa dengan sengaja melakukan tindakan yang menguntungkan salah satu pasangan calon selama masa kampanye pada Satuan Reserse Kriminal (Satreskrim) Kepolisian Resor Pariaman telah dilaksanakan dan perkaranya telah dinyatakan lengkap (P.21) oleh Penuntut Umum Kejaksaan Negeri Pariaman, namun tidak berarti tidak ada kendala-kendala yang ditemui dalam pelaksanaan proses penyidikannya.

Berdasarkan hasil penelitian yang penulis lakukan terkait dengan kendala-kendala yang dihadapi dalam penyidikan terhadap kepala desa yang dengan sengaja melakukan tindakan yang menguntungkan salah satu pasangan calon selama masa kampanye pada Satuan Reserse Kriminal Kepolisian Resor Pariaman, diperoleh penjelasan bahwa: ada 2 (dua) hambatan atau kendala, yaitu, pertama, kendala internal dan kedua, kendala eksternal antara lain:

1. Kendala Internal, yaitu kendala atau hambatan yang berasal dari dalam institusi Sentra Penegakan Hukum Terpadu dan Penyidik, antara lain:

a. Masih adanya perbedaan penafsiran terhadap unsur-unsur tindak pidana pemilihan, khususnya ketentuan Pasal 77 dan Pasal 188 Undang-undang Nomor 10 tahun 2016.

b. Terbatasnya waktu untuk melakukan pengkajian terhadap dugaan tindak pidana pemilihan, karena hanya diberikan waktu 7 (tujuh) hari sejak kejadian, sehingga penanganannya tidak komprehensif.

c. Tidak ada kejelasan mengenai jangka waktu pelaporan apakah hari libur dihitung atau tidak.

d. Tingkat pemahaman yang masih kurang dari anggota Sentra Gakkumdu terhadap peraturan perundang-undangan yang mengatur tentang pemilihan kepala daerah.

e. Kurangnya koordinasi antara personel yang duduk dalam Sentra Gakkumdu.

f. Masih adanya hambatan psikologis bagi anggota Sentra Gakkumdu, khususnya dari unsur Kepolisian dan Kejaksaan dalam menangani tindak pidana pemilihan kepala daerah, karena penuh dengan muatan politik.

2. Kendala Eksternal, yaitu kendala atau hambatan yang berasal dari luar institusi Sentra Penegakan Hukum Terpadu dan penyidik, antara lain: 
a. Ketentuan dan peraturan perundang-undangan yang mengatur tentang pelaksanaan pemilihan kepala daerah masih terlalu longgar dan banyak celah yang bisa dimanfaatkan pihak-pihak yang berkepentingan, sehingga belum bisa menjerat para pelaku.

b. Terbatasnya kewenangan yang dimiliki Bawaslu dan Sentra Gakkumdu serta Penyidik Polri dalam penanganan tindak pidana pemilihan kepala daerah.

c. Terbatasnya barang bukti dan alat bukti yang dimiliki Sentra Gakkumdu berkaitan dengan kasus dugaan pelanggaran tindak pidana pemilihan kepala daerah.

d. Ketakutan dan kekhawatiran para saksi untuk memenuhi panggilan dan diminta keterangannya berkaitan dengan tindak pidana pemilihan kepala daerah.

e. Masih adanya intervensi dari Partai Politik dan pasangan calon kepala daerah terhadap unsur dalam Sentra Gakkumdu untuk tidak meneruskan dugaan tindak pidana pemilihan ke ranah hukum.

Beranjak dari kendala-kendala yang dihadapi dalam penyidikan tindak pidana pemilihan kepala daerah sebagaimana yang telah dipaparkan di atas, maka perlu dilakukan upaya untuk mengatasi kendala dimaksud. Berdasarkan hasil penelitian yang penulis lakukan berkaitan dengan upaya yang dilakukan untuk mengatasi kendala dalam penyidikan tindak pidana pemilihan pada Satuan Reserse Kriminal Kepolisian Resor Pariaman diperoleh penjelasan sebagai berikut:

1. Membuat standar operasional prosedur (SOP) penanganan tindak pidana pemilihan kepala daerah sebagai pedoman bagi Sentra Gakkumdu dan penyidik Polri.

2. Sikap tegas pengawas pemilu yang meneruskan laporan dan atau temuan-temuan tindak pidana pemilihan ke penyidik, khususnya menyangkut perbuatan mana yang sudah memenuhi unsur-unsur tindak pidana pemilihan.

3. Menyamakan pemahaman dan persepsi antara Bawaslu dengan Penyidik yang dimanifestasikan secara konkrit di dalam pola penanganan perkara yang ada.

4. Memberikan kesempatan bagi para pihak untuk memaksimalkan waktu yang ada dalam mencari bukti-bukti yang dibutuhkan.

5. Mengoptimalkan mekanisme pleno, karena melalui mekanisme inilah maka kesepahaman antar para pihak atas apakah suatu perbuatan memenuhi tindak pidana, atau tidak dapat tercapai, sehingga suatu tindak pidana dapat langsung diidentifikasi dan pihak Kepolisian pun dapat langsung menindaknya.

6. Membuka kerja sama dengan semua pihak dalam melakukan pengusutan terhadap suatu dugaan tindak pidana. Kerjasama disini dapat dilakukan, bahkan sejak suatu laporan/temuan tersebut dimiliki oleh Panitia Pengawas Pemilihan dengan memberikan 
kesempatan untuk berkordinasi, terutama kepada pihak Kepolisian Negara Republik Indonesia ketika melakukan pengkajian atas laporan/temuan tersebut.

7. Merubah jenis laporan dugaan tindak pidana Pemilihan dari masyarakat menjadi temuan Bawaslu, sehingga tidak akan sulit mencari saksi, karena saksinya adalah dari anggota Bawaslu.

Memberikan jaminan perlindungan kepada saksi karena bukan tidak mungkin saksi akan diteror dan diancam oleh pihak terlapor.

\section{PENUTUP}

Berdasarkan hasil dan pembahasan sebagaimana yang telah dipaparkan di atas, maka penulis dapat menarik kesimpulan/ penutup sebagai berikut:

1. Pelaksanaan penyidikan terhadap kepala desa yang dengan sengaja melakukan tindakan yang menguntungkan salah satu pasangan calon selama masa kampanye pada Satuan Reserse Kriminal Kepolisian Resor Pariaman didasarkan pada Undang-undang Pemilihan Kepala Daerah dan Undang-undang Kepolisian serta Peraturan Kapolri tentang manajemen penyidikan tindak pidana, dengan mekanisme (1) menerima laporan, (2) melakukan penyelidikan, (3) penanganan dan pengolahan tempat kejadian perkara, (4) melakukan penyidikan, (5) penggunaan upaya paksa berupa penangkapan dan penyitaan, (6) pemeriksaan saksi-saksi, saksi ahli dan pemeriksaan tersangka serta (7) menyerahkan tersangka dan barang bukti kepada kepada penuntut umum.

2. Kendala-kendala yang dihadapi dalam penyidikan terhadap kepala desa yang dengan sengaja melakukan tindakan yang menguntungkan salah satu pasangan calon selama masa kampanye pada Satuan Reserse Kriminal Kepolisian Resor Pariaman ada 2 (dua) kendala, yaitu: (1) kendala internal, antara lain: adanya perbedaan penafsiran terhadap unsur-unsur tindak pidana pemilihan kepala daerah, terbatasnya waktu untuk melakukan pengkajian, tidak ada kejelasan mengenai jangka waktu pelapor, pemahaman yang masih kurang dari anggota Sentra Gakkumdu, kurangnya koordinasi antara personel yang duduk dalam Sentra Gakkumdu, adanya hambatan psikologis bagi anggota Sentra Gakkumdu, dan (2) kendala eksternal, antara lain: adanya kelemahan peraturan pilkada, terbatasnya kewenangan yang dimiliki Bawaslu dan Penyidik Polri, kurangnya alat bukti, ketakutan menjadi saksi, adanya intervensi dari Partai Politik dan 
pasangan calon kepala daerah. Adapun upaya untuk mengatasi kendala dimaksud dengan cara: membuat standar operasional prosedur (SOP) penanganan tindak pidana pemilihan kepala daerah, ketegasan pengawas pemilu, menyamakan pemahaman dan persepsi, memaksimalkan waktu yang ada dalam mencari bukti-bukti yang dibutuhkan, membuka kerja sama dengan semua pihak dan merubah jenis laporan dugaan tindak pidana Pemilihan dari masyarakat menjadi temuan Bawaslu serta memberikan jaminan perlindungan kepada saksi.

\section{DAFTAR PUSTAKA}

\section{Buku Teks:}

Amir Ilyas, Asas-Asas Hukum Pidana, Rengkang Education Yogyakarta dan Pukap Indonesia, Yogyakarta, 2012

Andi Hamzah, Asas-Asas Hukum Pidana, Cetakan Keempat, PT Rienka Cipta, Jakarta, 2010

C.S.T. Kansil dan Christine., Pokok-Pokok Hukum Pidana, PT. Pradnya Paramita, Jakarta, 2007

Dedi Mulyadi, Kebijakan Legislasi tentang Sanksi Pidana Pemilu Legislatif Di Indonesia dalam Perspektif Indonesia, Jakarta, Gramata Publishing, 2012

Djoko Prakoso, Tindak Pidana Pemilu, Sinar Harapan, Jakarta, 1987

Faisal Salam, Hukum Acara Pidana Dalam Teori dan Praktek, Mandar Maju, Bandung, 2001

Hamrat Hamid, Pembahasan Permasalahan KUHAP bidang Penuntutan dan Eksekusi, Jakarta, Sinar Grafika, 1992

Mahrus Ali, Dasar-dasar Hukum Pidana, Sinar Grafika, Jakarta, 2011

Mardjono Reksodiputro, Sistem Peradilan Pidana Indonesia (Peran Penegak Hukum Melawan Kejahatan), Pusat Pelayanan Keadilan Dan Pengabdian Hukum, Universitas Indonesia (UI) Jakarta, 1994

Moeljatno, Asas-Asas Hukum Pidana, Rineka Cipta, Jakarta, 1993

P.A.F. Lamintang, Delik-Delik Khusus: Kejahatan-Kejahatan Terhadap Kepentingan Hukum Negara,Cetakan I, Sinar Baru, Bandung, 1987

Romli Atmasasmita, Sistem Peradilan Pidana Kontemporer, Kencana Prenada Media Group, Jakarta, 2010

Ronny Hanitijo Soemitro, Metodologi Penelitian Hukum Dan Jurimetri, Ghalia Indonesia, Jakarta, 1993

Topo Santoso, Tindak Pidana Pemilu, Sinar Grafika, Jakarta, 2006 
Yesmil Anwar dan Adang, Sistem Peradilan Pidana: Konsep, Komponen dan Pelaksanaannya Dalam Penegakan Hukum, Widya Padjajaran, Bandung, 2009

\section{Peraturan Undang-Undang :}

Undang-undang Nomor 1 Tahun 2015 tentang Penetapan Peraturan Pemerintah Pengganti Undang-Undang Nomor 1 Tahun 2014 tentang Pemilihan Gubernur, Bupati, dan Walikota 